\title{
C45 Algorithm for Creative Economic Products and Services Marketing Classification of Padang
}

\author{
Dinul Akhiyar ${ }^{1}$ and Irzal Arif Wisky ${ }^{2}$ \\ \{dinul_akhiyar@upiyptk.ac.id ${ }^{12}$ \} \\ Faculty of Computer Science, Universitas Putra Indonesia YPTK Padang, Indonesia ${ }^{12}$
}

\begin{abstract}
The aims of this research were to analyze the marketing data for creative economy products and services in Padang using the C45 algorithm. Nowadays, the development of information technology is one of the factors that play a role in the marketing of products and services in creative economy. The $\mathrm{C} 45$ algorithm is able to classify how big influence the existing marketing factors have on the transaction. This research resulted in a classification of the level of sales of products and services, namely less famous, famous, and very famous. The results of this study are used to reference the development of integrated digital-based marketing concepts.
\end{abstract}

Keywords: C45 Algorithm; Creative Economic; Marketing Classification

\section{Introduction}

Padang is one of the cities that have a fairly good development of creative economy in Padang, including a center for souvenirs, culinary, and cultural performances [1] This happens because of various factors, including the development of the tourism sector, the good governance of people's economic enterprises [2]. This will encourage the emergence of a creative industry that has good competitiveness. Reports on the development of the creative economy of Padang are carried out annually, like fashion, performance services / culture, souvenirs [3]. The dominating application of digital marketing for marketing is social media marketing.

Marketing of creative economy products and services in Padang must be supported by integrated marketing channels, so that the current form of marketing can be more optimal [4]. So that digital-based marketing or what is commonly called digital marketing can optimize the use of social media [5][6]. The use of information technology in the marketing of creative economic products and services is able to provide good added value to improve the best service to consumers [6][4]. This will increase growth in the creative economy business [7]

The use of digital marketing in small and medium enterprises can increase sales [8]and digital marketing can provide good data processing support [9]. So, there is no reason not to apply this digital marketing technology [10]. Social media is one form of digital marketing that has been widely applied in various business fields, this will provide the input of digital technology needs that are needed today [11][12]. Apart from social media, another type of digital marketing is email marketing, where email plays a role in marketing products and services in an industry or company, which is sent directly to registered consumer e-mails [13][14]. 
The thing that needs to be considered in digital marketing is how to make consumers explore the products and services we sell so that they will be able to increase marketing [12][15]. Analysis needs to be done using data mining algorithms to produce decision support in implementing and choosing the type of digital marketing [16] [17][5][14][18].

\section{Method}

To develop the marketing of creative economy products and services in Padang, it is necessary to first analyze the marketing data. Marketing data analysis in this study used one of the data mining algorithms, namely $\mathrm{C} 4.5$. The $\mathrm{C} 4.5$ algorithm is able to predict the classification of factors that affect the marketing of products and services for creative economy actors. The results of this analysis will become a reference in the development of marketing of creative economy products and services in Padang with the concept of Customer Relationship Management (CRM).

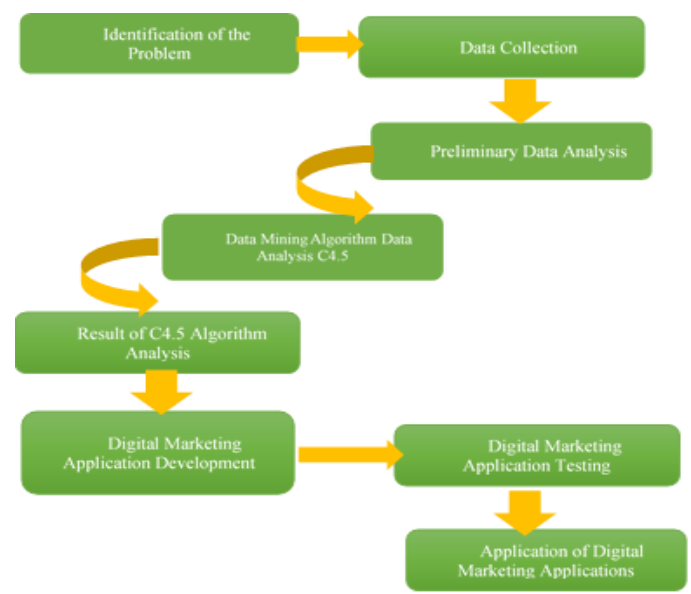

Fig 1. Research Framework

This research used a combination method, begins with identification of the problem then $\mathrm{p}$ data collection and preliminary data analysis stages, in analyzing the data used c4.5 data mining algorithm, the results of data analysis are used to refer to the development of digital marketing applications, then the application is tested to be ready. To be implemented, for more details, the stages of the research can be seen in Figure 1. After identifying the problem, data collection is carried out. The initial data that is collected is marketing data to be analyzed, namely data from Padang creative economy actors obtained from the Padang creative economy book in 2018.

In addition, the data taken from the book, to find out various factors that influence the marketing of creative economy products in Padang, then the researcher conducted a field survey and submitted a questionnaire related to marketing factors. The collected data is carried out preliminary analysis to be able to produce sample data or initial data. This initial data will be processed with data mining algorithm C.45 to perform marketing predictions. Then the results of this analysis will be used as a reference for the development of digital marketing applications, then the digital marketing application trial will be carried out and finally the 
implementation of the digital marketing application in the creative economy players in Padang.

\section{Result and Discussion}

To develop the marketing of creative economy products and services in Padang, it is necessary to first analyze the marketing data. Marketing data analysis in this study used one of the data mining algorithms, namely $\mathrm{C} 4.5$. The $\mathrm{C} 4.5$ algorithm is able to classify the factors that influence the marketing of products and services for creative economy actors. The results of this analysis will become a reference in the development of marketing of creative economy products and services in the city of Padang with the concept of Customer Relationship Management (CRM).

The marketing data analyzed is data from Padang creative economy actors obtained from the Padang creative economy book in 2018. In addition to the data taken from the book to find out various factors that affect the marketing of creative economy products in the city of Padang, the authors conducted a field survey and submitting a questionnaire related to marketing factors. The collected data is carried out preliminary analysis to be able to produce sample data. For more details, the sample data used can be seen in table 4.1

Table 1. Padang Creative Economy Marketing Data

\begin{tabular}{|c|c|c|c|c|c|c|c|c|c|}
\hline No. & Creative Economy List & $\begin{array}{l}\text { Type Of } \\
\text { Business }\end{array}$ & $\begin{array}{l}\text { Business } \\
\text { Location }\end{array}$ & $\begin{array}{c}\text { Product } \\
\text { Prices }\end{array}$ & $\begin{array}{l}\text { Social Media } \\
\text { Promotion }\end{array}$ & $\begin{array}{c}\text { E Commerce } \\
\text { Marketing }\end{array}$ & $\begin{array}{l}\text { Product } \\
\text { Quality }\end{array}$ & $\begin{array}{l}\text { Type Of } \\
\text { Product }\end{array}$ & Popularity \\
\hline 1 & $\begin{array}{l}\text { Pusat Oleh Oleh Ummi } \\
\text { Aufa Hakim }\end{array}$ & $\begin{array}{l}\text { Kuliner } \\
\text { Cemilan }\end{array}$ & Strategic & Standard & Yes & No & Good & Many & Famous \\
\hline 2 & Sitti Nurbaya Food & $\begin{array}{l}\text { Kuliner } \\
\text { Makanan }\end{array}$ & Strategic & Standard & Yes & Yes & Good & Many & Famous \\
\hline 3 & $\begin{array}{c}\text { Keripik Balado Cristine } \\
\text { Hakim-Asli Padang }\end{array}$ & $\begin{array}{l}\text { Kuliner } \\
\text { Cemilan }\end{array}$ & Strategic & Compete & Yes & Yes & Good & Many & Very Famous \\
\hline 4 & $\begin{array}{l}\text { Keripik Balado Rohana } \\
\text { Kudus }\end{array}$ & $\begin{array}{l}\text { Kuliner } \\
\text { Cemilan }\end{array}$ & Strategic & Standard & Yes & Yes & Good & Many & Famous \\
\hline 5 & Keripik Balado $4 \times 7$ & $\begin{array}{l}\text { Kuliner } \\
\text { Cemilan }\end{array}$ & Strategic & Standard & Yes & Yes & Good & Many & Famous \\
\hline 6 & Keripik Balado Mahkota & $\begin{array}{l}\text { Kuliner } \\
\text { Cemilan }\end{array}$ & Strategic & Standard & Yes & Yes & Good & Many & Famous \\
\hline 7 & $\begin{array}{l}\text { Rumah Makan Ampalu } \\
\text { Raya }\end{array}$ & $\begin{array}{l}\text { Kuliner } \\
\text { Makanan }\end{array}$ & Strategic & Standard & No & No & Good & Many & Famous \\
\hline 8 & Rajo Bengkuang Wh 8 & $\begin{array}{l}\text { Kuliner } \\
\text { Cemilan }\end{array}$ & Less & Standard & No & No & Good & Little & Less Famous \\
\hline 9 & $\begin{array}{l}\text { Batik Tanah Like Bundo } \\
\text { Kanduang }\end{array}$ & Kriya & Strategic & Standard & Yes & No & Good & Many & Famous \\
\hline 10 & Yadir Fashion Designer & Fashion & Strategic & Compete & Yes & No & Good & Many & Famous \\
\hline 11 & $\begin{array}{c}\text { Novia Hertini Fashion } \\
\text { Designer }\end{array}$ & Fashion & Less & Compete & Yes & No & Good & Many & Less Famous \\
\hline 12 & $\begin{array}{l}\text { De Irma Fashion } \\
\text { Designer }\end{array}$ & Fashion & Strategic & Compete & Yes & No & Good & Many & Famous \\
\hline 13 & $\begin{array}{l}\text { Rumah Tenun Nelvi } \\
\text { Silungkang Pandai } \\
\text { Sikek }\end{array}$ & Kriya & Strategic & Standard & Yes & No & Good & Many & Famous \\
\hline
\end{tabular}




\begin{tabular}{|c|c|c|c|c|c|c|c|c|c|}
\hline 14 & Bordir Mande & Kriya & Less & Standard & Yes & No & Good & Many & Less Famous \\
\hline 15 & $\begin{array}{l}\text { Keripik Balado Sutan } \\
\text { Pangeran }\end{array}$ & $\begin{array}{l}\text { Kuliner } \\
\text { Cemilan }\end{array}$ & Strategic & Standard & Yes & No & Good & Many & Famous \\
\hline 16 & $\begin{array}{l}\text { Heni Adli Minangkabau } \\
\text { Kraft Village }\end{array}$ & Fashion & Less & Compete & Yes & No & Good & Many & Famous \\
\hline 17 & Rendang Suir Wh 8 & $\begin{array}{l}\text { Kuliner } \\
\text { Makanan }\end{array}$ & Strategic & Standard & Yes & Yes & Good & Little & Less Famous \\
\hline 18 & $\begin{array}{c}\text { Tampuruang Barendo } \\
\text { Handy Craft }\end{array}$ & Kriya & Less & Standard & Yes & Yes & Good & Little & Less Famous \\
\hline 19 & Annisa Tali Ameh & Kriya & Less & Less & No & No & Reguler & Little & Less Famous \\
\hline 20 & $\begin{array}{l}\text { Rumah Rendang Awak } \\
\text { Juo }\end{array}$ & $\begin{array}{l}\text { Kuliner } \\
\text { Makanan }\end{array}$ & Less & Standard & Yes & Yes & Good & Little & Less Famous \\
\hline 21 & Rumah Makan Keluarga & $\begin{array}{c}\text { Kuliner } \\
\text { Makanan }\end{array}$ & Strategic & Standard & No & No & Good & Many & Less Famous \\
\hline 22 & $\begin{array}{c}\text { Rumah Makan Muaro } \\
\text { Baru } \\
\end{array}$ & $\begin{array}{l}\text { Kuliner } \\
\text { Makanan }\end{array}$ & Reguler & Standard & Yes & No & Good & Many & Famous \\
\hline 23 & $\begin{array}{c}\text { Opicha Craft Kerajinan } \\
\text { Daur Ulang }\end{array}$ & Kriya & Less & Standard & Yes & Yes & Good & Many & Famous \\
\hline 24 & $\begin{array}{l}\text { Silvia Piobang } \\
\text { Handycraft }\end{array}$ & Kriya & Less & Standard & Yes & Yes & Good & Many & Less Famous \\
\hline 25 & $\begin{array}{c}\text { Bubuk Nabati } \\
\text { Mungbean }\end{array}$ & $\begin{array}{l}\text { Kuliner } \\
\text { Minuman }\end{array}$ & Less & Standard & Yes & Yes & Good & Many & Less Famous \\
\hline 26 & $\begin{array}{l}\text { Rumah Makan Pagi } \\
\text { Sore }\end{array}$ & $\begin{array}{l}\text { Kuliner } \\
\text { Makanan }\end{array}$ & Strategic & Standard & Yes & No & Good & Many & Famous \\
\hline 27 & Asese & $\begin{array}{l}\text { Kuliner } \\
\text { Makanan }\end{array}$ & Strategic & Compete & Yes & Yes & Good & Many & Very Famous \\
\hline 28 & $\begin{array}{l}\text { Doni Rahman Fashion } \\
\text { Designer }\end{array}$ & Fashion & Strategic & Compete & Yes & No & Good & Many & Famous \\
\hline 29 & Rimbun Coffe & $\begin{array}{c}\text { Kuliner } \\
\text { Minuman }\end{array}$ & Strategic & Compete & Yes & No & Good & Many & Famous \\
\hline 30 & $\begin{array}{c}\text { Percetakan Lado Kutu } \\
\text { Offside }\end{array}$ & $\begin{array}{l}\text { Desain } \\
\text { Produk }\end{array}$ & Less & Compete & Yes & No & Good & Many & Famous \\
\hline 31 & Soto Garuda & $\begin{array}{c}\text { Kuliner } \\
\text { Makanan }\end{array}$ & Strategic & Compete & Yes & No & Good & Little & Famous \\
\hline 32 & Rumah Makan Bernama & $\begin{array}{l}\text { Kuliner } \\
\text { Makanan }\end{array}$ & Strategic & Compete & Yes & No & Good & Many & Less Famous \\
\hline
\end{tabular}

\subsection{Decision Tree}

Decision tree is the result of data testing using Rapid Maner software. Where it can be seen that the marketing factors that influence a creative economy become famous, less famous and very famous, if the creative economy actors have a few types of products then we need to look at the business location, if the business location is lacking then it is certain that the creative economy is less famous, but if strategic business location it will be famous. If the type of product sold by the creative economy, it is necessary to see whether it is using e-commerce marketing, if not then the creative economy actors will be famous, if so then we need to look again at the product price, the right product price will make this creative economy actor become very famous.

However, if the product price is standard, it is necessary to look at the location of the business. If the business location is lacking, it will be less famous, but if the business location is strategic, it will become famous. 


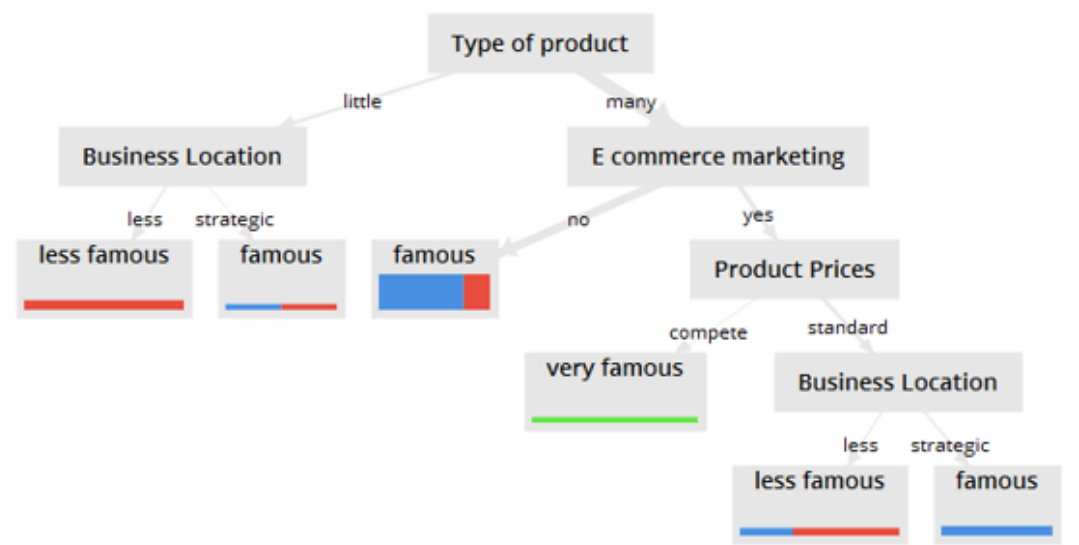

Fig 2. The Creative Economy Marketing Analysis Decision Tree of Padang City

\section{Tree}

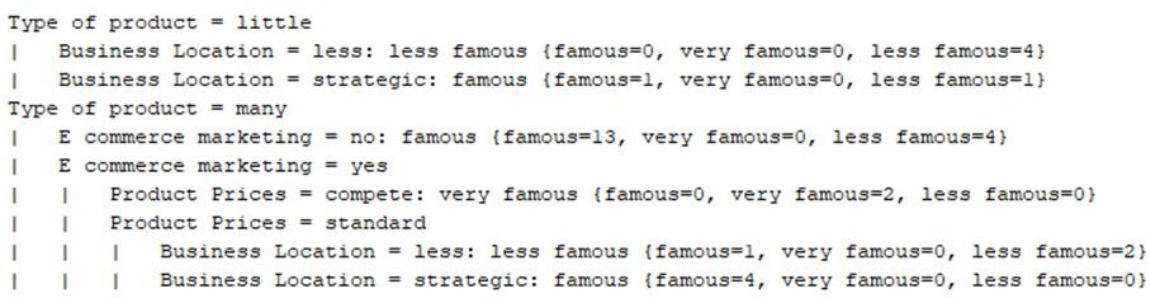

Fig 3. Creative Economy Marketing Analysis Tree of Padang City

\section{Conclusion}

This research produces decision support in the form of a decision tree using the $\mathrm{C} 45$ data mining algorithm. The marketing data for the creative industry in Padang were collected, analyzed, processed and tested using RapidMiner software. The classification that is formed from the $\mathrm{C} 45$ analysis consists of three, namely, very famous, famous, and less famous. The factors that cause these creative industry players to be included in one of these parts depend on the conditions of the factors that affect their marketing. This research needs to be carried out for more and more diverse numbers of creative economy industry players in Padang, not only recorded by the relevant agencies, but also direct searches in the field, so that more data is processed.

\section{Acknowledgement}

We would like to thank to Universitas Putra Indonesia YPTK Padang for providing funding for the Research Grant 2020 For Applied Skim (Terapan) and fully supported by the Padang Computer College Foundation. 


\section{References}

[1] V. B. Kumbara, M. Afuan, and R. B. Putra, "THE EFFECT OF EXPERIMENTAL MARKETING ON REVISIT INTENTION TOURISTS IN MANDEH ISLAND TOURISMN OBJECT , PESISIR SELATAN REGENCY," vol. 2, pp. 73-81, 2020.

[2] P. Foroudi, S. Gupta, A. Nazarian, and M. Duda, "Digital technology and marketing management capability: achieving growth in SMEs," Qual. Mark. Res., vol. 20, no. 2, pp. 230-246, 2017, doi: 10.1108/QMR-01-2017-0014.

[3] A. Muhammad and E. P. W. Mandala, "Aplikasi Customer Relationship Management Dalam Pemasaran Songket Silungkang Kota Sawahlunto,” Teknologi, vol. 6, no. 2, pp. 52-59, 2018, [Online]. Available: http://lppm.upiyptk.ac.id/teknologi/index.php/TEKNOLOGI/article/view/111.

[4] E. W. T. Ngai, K. L. K. Moon, S. S. Lam, E. S. K. Chin, and S. S. C. Tao, "Social media models, technologies, and applications: An academic review and case study," Ind. Manag. Data Syst., vol. 115, no. 5, pp. 769-802, 2015, doi: 10.1108/IMDS-03-2015-0075.

[5] K. J. Trainor, J. Andzulis, A. Rapp, and R. Agnihotri, "Social media technology usage and customer relationship performance: A capabilities-based examination of social CRM," J. Bus. Res., vol. 67, no. 6, pp. 1201-1208, 2014, doi: 10.1016/j.jbusres.2013.05.002.

[6] G. Piccoli, T. W. Lui, and B. Grün, "The impact of IT-enabled customer service systems on service personalization, customer service perceptions, and hotel performance," Tour. Manag., vol. 59, pp. 349-362, 2017, doi: 10.1016/j.tourman.2016.08.015.

[7] T. H. Song, S. Y. Kim, and J. Y. Kim, "The dynamic effect of customer equity across firm growth: The case of small and medium-sized online retailers," J. Bus. Res., vol. 69, no. 9, pp. 3755-3764, 2016, doi: 10.1016/j.jbusres.2015.12.067.

[8] H. M. Taiminen and H. Karjaluoto, "The usage of digital marketing channels in SMEs," J. Small Bus. Enterp. Dev., vol. 22, no. 4, pp. 633-651, 2015, doi: 10.1108/JSBED-05-2013-0073.

[9] T. A. Monteiro, A. C. Giuliani, N. K. Pizzinatto, and E. Larios-Gomez, "Managing the digital consumer: insights from Brazil and Spain,” J. Manuf. Technol. Manag., vol. 30, no. 8, pp. 11961215, 2019, doi: 10.1108/JMTM-12-2017-0272.

[10] G. Alfian, M. F. Ijaz, M. Syafrudin, M. A. Syaekhoni, N. L. Fitriyani, and J. Rhee, "Customer behavior analysis using real-time data processing: A case study of digital signage-based online stores,” Asia Pacific J. Mark. Logist., vol. 31, no. 1, pp. 265-290, 2019, doi: 10.1108/APJML-032018-0088.

[11] N. Morris, "Understanding Digital Marketing: Marketing Strategies for Engaging the Digital Generation," J. Direct, Data Digit. Mark. Pract., vol. 10, no. 4, pp. 384-387, 2009, doi: 10.1057/dddmp.2009.7.

[12] M. Yadav and Z. Rahman, "The influence of social media marketing activities on customer loyalty: A study of e-commerce industry," Benchmarking, vol. 25, no. 9, pp. 3882-3905, 2018, doi: 10.1108/BIJ-05-2017-0092.

[13] M. Hartemo, "Email marketing in the era of the empowered consumer," J. Res. Interact. Mark., vol. 10, no. 3, pp. 212-230, 2016, doi: 10.1108/JRIM-06-2015-0040.

[14] S. Dwiasnati and Y. Devianto, "Utilization of Prediction Data for Prospective Decision Customers Insurance Using the Classification Method of C.45 and Naive Bayes Algorithms," J. Phys. Conf. Ser., vol. 1179, no. 1, 2019, doi: 10.1088/1742-6596/1179/1/012023.

[15] M. A. Abdillah and A. Setyanto, "Implementasi Decision Tree Algoritma C4 . 5 Untuk Memprediksi Kesuksesan Pendidikan Karakter," vol. XV, pp. 59-69, 2020.

[16] C. Series, "Comparison of algorithm Support Vector Machine and C4 . 5 for identification of pests and diseases in chili plants Comparison of algorithm Support Vector Machine and C4 . 5 for identification of pests and diseases in chili plants," 2019, doi: 10.1088/1742-6596/1402/6/066104.

[17] J. D'Haen, D. Van Den Poel, and D. Thorleuchter, "Predicting customer profitability during acquisition: Finding the optimal combination of data source and data mining technique," Expert Syst. Appl., vol. 40, no. 6, pp. 2007-2012, 2013, doi: 10.1016/j.eswa.2012.10.023.

[18] W. Wiguna and D. Riana, "Diagnosis of Coronavirus Disease 2019 (Covid-19) Surveillance Using C4.5 Algorithm," J. Pilar Nusa Mandiri, vol. 16, no. 1, pp. 71-80, 2020, doi: 10.33480/pilar.v16i1.1293. 